\title{
Towards Developing Sustainable Smart Cities in India
}

\author{
Shruti, Prabhat Kumar Singh, Anurag Ohri
}

\begin{abstract}
The present paper provides a comprehensive review of frameworks for Sustainable and Smart Cities. The key findings highlight the large gap between the concept of Smart Cities and Environmental Sustainability. We recommend to improve the sustainability quotient by incorporating the use of Information and Communication Technology, thus developing Sustainable Smart Cities. In India, the stipulated guidelines regarding Smart Cities have been proposed by Ministry of Urban Development (MOUD) and 14 environmental indicators have been proposed. The extensive review of literature and the present guidelines demands an urgent need of framework for Sustainable Smart Cities in India. Moreover, the indicators selected must fulfill the criteria for smartness and sustainability. The paper concludes by suggesting a framework comprising of four steps: Indicator selection, Benchmarking, Assigning weights and development of Sustainable Smart Cities Environmental Index by the use of selected indicators. The framework developed in this order ensures the Sustainable Smart Cities appear attainable in India.
\end{abstract}

Keywords: Framework, Smart Cities, Sustainable Cities, Sustainable Smart Cities.

\section{INTRODUCTION}

Cities are the drivers of growth, economic activity and thus considered as engine for extensive development. The mushrooming of class I and class II cities is the result of the rapid urbanization in India [1]. The progressive growth in cities has exerted a sheer pressure for providing development and environment sustainability. The urban transition through which India is going on can be overcome by transforming the existing cities into 'Smart Cities'. Boyd Cohen [2] presented a wheel model of smart cities (Fig. 1). This frame work discussed six components of a smart city: Smart mobility (utilising the benefit of mobile service and clean urban mobility by means of ICT), Smart people (inclusion of citizen creativity and awareness to develop a sustainable city), Smart governance (transparency in the government services provided), Smart environment (improving the deteriorating climatic conditions by sustainable planning), Smart economy

Revised Manuscript Received on December 30, 2019.

* Correspondence Author

Shruti*, Department of Civil Engineering, IIT (BHU), Varanasi, India. Email: drshrutisingh984@gmail.com

Prabhat Kumar Singh, Department of Civil Engineering, IIT (BHU),

Varanasi, India. Email: psingh.civ@iitbhu.ac.in

Anurag Ohri, Department of Civil Engineering, IIT (BHU), Varanasi, India.. Email: aohri.civ@iitbhu.ac.in

(c) The Authors. Published by Blue Eyes Intelligence Engineering and Sciences Publication (BEIESP). This is an open access article under the CC BY-NC-ND license (http://creativecommons.org/licenses/by-nc-nd/4.0/) (entrepreneur skill and innovation), and, Smart living (being healthy and safe). This framework attempted to develop a universal model for all cities and presented a more technical description of smart city by covering broader range of spectrum.

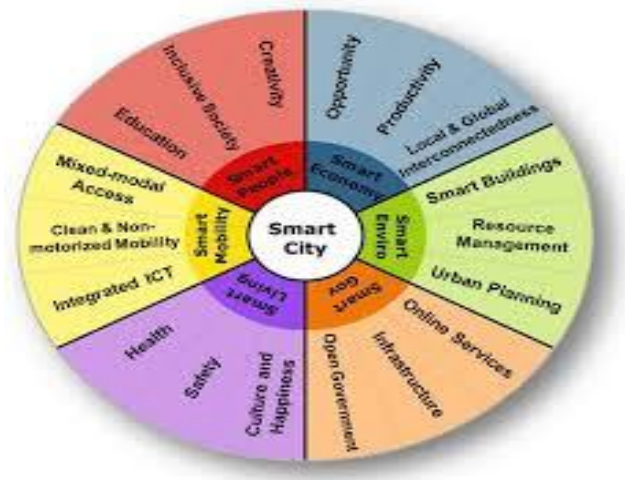

Fig. 1. Wheel Model of Smart City [2]

Ministry of Urban Development (MoUD), Government of India announced Smart Cities Mission (SCM) in June 2015 [3]. Adequate water supply, sanitation including solid waste management etc. form the core infrastructure elements of this program. The guidelines for preparation of Smart City Proposal (SCP) along with application of smart solutions include 14 indicators which relate to environment (Table I). Before the advent of SCM in India, many initiatives were taken as a part of city development programs. In the year 2005-06, Jawaharlal Nehru National Urban Renewal Mission (JNNRUM) was commenced for a period of seven years (2005-2012). The objective of this mission was to upgrade the urban infrastructure and governance [4]. Inappropriate urban planning, delay in project implementation, and leveraging of funds were found as some of the difficulties in this initiative. JNNRUM was replaced by Atal Mission for Rejuvenation and Urban Transformation (AMRUT) in 2015 to focus on infrastructure creation. 500 cities were selected to provide better services in the field of water supply, sewerage, septage, storm water drainage etc. The universal coverage of indicators are to be ensured in five years of the mission, but in case of lack of funds, priority will be given to the water supply followed by the sewerage [5]. Heritage City Development and Augmentation Yojana (HRIDAY) was launched in 2017 to develop basic services in heritage cities. Its implementation will be program based rather than project based [6]. The programs initiated by Government of India focuses on delivering infrastructure utilities and services but had not explored the sustainability quotient [1]. Thus, SCM can be inline with the vision of sustainability for development of Sustainable Smart Cities [7].

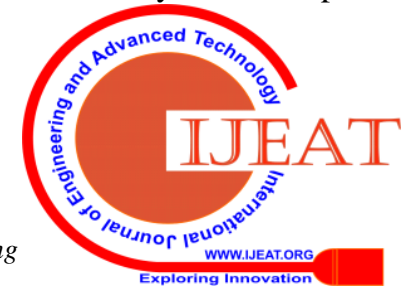


Table I. Environmental Indicators in Smart City Mission, Government of India [3]

\begin{tabular}{|c|c|}
\hline \multirow{4}{*}{ Waste Management } & 1) Waste to energy and fuel \\
\hline & 2) Waste to compost \\
\hline & $\begin{array}{l}\text { 3) Recycling and reduction of construction and } \\
\text { demolition waste }\end{array}$ \\
\hline & $\begin{array}{l}\text { 4)Solid waste management programs carried in } \\
\text { the city during last } 3 \text { years }\end{array}$ \\
\hline \multirow{5}{*}{ Water Management } & 5) Smart meters and Management \\
\hline & 6) Leakage identification \\
\hline & 7) Water quality monitoring \\
\hline & 8) Adequate water supply \\
\hline & 9) Extent of cost recovery in water supply services \\
\hline \multirow{3}{*}{$\begin{array}{l}\text { Sewerage and } \\
\text { Sanitation }\end{array}$} & 10) Coverage of toilets \\
\hline & 11) Waste water recycling \\
\hline & 12) Extent of cost recovery \\
\hline $\begin{array}{l}\text { Storm Water } \\
\text { Drainage }\end{array}$ & 13) Storm water reuse \\
\hline Pollution & 14) Improvement in air quality \\
\hline
\end{tabular}

\section{FRAMEWORKS FOR SUSTAINABLE CITIES AND SMART CITIES}

The sustainable developments from economic, social and environmental point of view have been seen as an area of concern in global scenario since long. There is also growing interest in evaluating the implementation of policies by various organizations and how well they are satisfying their area specific objectives and global commitments. Several frameworks incorporating different set of indicators have been developed for evaluation of sustainability and formulation of policies by decision makers.

Organisation for Economic Co-operation and Development (OECD) of European Union in year 2001, came up with a set of 50 core indicators based on pressure-state-response (PSR) model to ensure the environmental concern into economic policies formulation and implementation for various sectors such as transport, energy and agriculture among the member countries of OECD [8].The World Bank Environment Department, in the year 2002, gave project based framework. The set of indicators in this framework intended to capture the effect of pressure and change in state to facilitate the decision-makers. The PSR framework was accordingly appended with "Impact" as fourth indicator category, thereby creating a pressure-state-impact-response (PSIR) model. Further, social and institutional aspects were added as a driving force indicator. Thus, the final form was modelled as driving force-pressure-state-impact-response (DPSIR) framework [9].

In 2012, Economist Intelligence Unit (EIU), reported development of Green city Index, to compare cities performance, keeping in view the negative effects, such as traffic congestions, urban settlement, environmental deterioration, exploitation of resources etc. on account of urban development. The Green City Index (GCI) includes 30 indicators which were categorized as quantitative indicators (where the data is obtained from official sources), and qualitative indicators (which assess the environmental policies and commitments of a city for a sustainable approach) [10]. Further, in year 2012, Lazaroiu and Roscia [11] developed methodology for the smart city model which was based on the six criteria of Boyd Cohen model. Indicators were selected for each of the criteria, weights were assigned to each of the indicator and fuzzy logic approach was applied to access the funds released from European commission.

In 2013, Urban Sustainability Index (USI) was developed in China comprising of 16 indicators [12]. These 16 indicators were sub-divided into five categories: Basic need, Resource efficiency, Environment Cleanliness, Built Environment and Commitment to sustainability with appropriate weight and emphasis were given on society and environment. This index system is mainly focused on growth level analysis rather than static analysis.

Government of Mauritius [13] issued environmental guidelines for smart cities. These guidelines lay down the environmental criteria, their objectives and the probable measures for Smart City projects. Joshi et.al in 2016 [14] developed a model for smart city considering six pillars for smart city framework: i. Social ii. Management iii. Economic, iv. Legal, v. Technology and vi. Sustainability (SMELTS). In this model it is considered that technological, economy and legal have greater impact on the development of smart city as compared to sustainability, social and management. The model is bifurcated in two levels in which the important components is kept in the inner level (Fig 2). The framework is mainly focussed on the use of information and communication technology (ICT) applications in the defined modules emphasising the governance and managerial aspect.

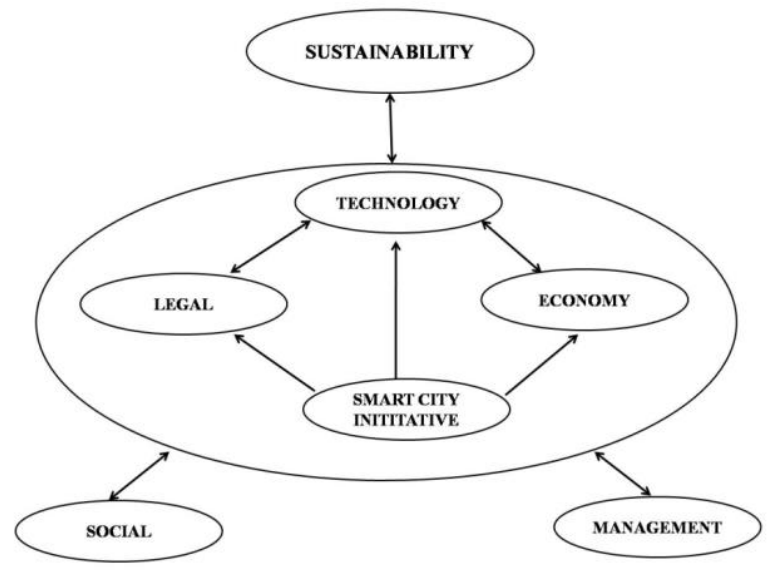

Fig. 2. SMELTS Framework for Smart City Initiative [14]

Sureshchandra et.al in 2016 [15] assessed the critical factors for designing the smart cities based on social survey outcomes considering mobility, physical factors, innovation and learning, political, information- communication and technological factors, environmental, operational and managerial, social and economic factors. Town planner, architect and project managers were asked to suggest the importance of these factors, using a total of 66 indicators. Among environmental factors, eight indicators were ranked in following order: 1. Recycling of used resources, 2.

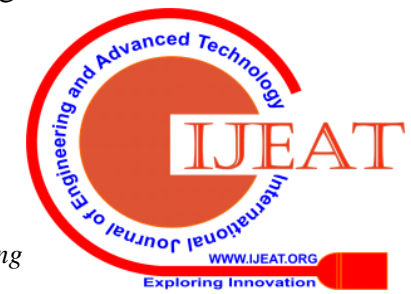


Sustainable resource management, 3. Environmental protection, 4. Consumption of energy from renewable sources, 5. Quality of resources, 6. Availability of Natural resources, 7. Greenhouse gas emission, and 8. Biodiversity. Based on ISO 37120, Bureau of Indian Standard (BIS) developed Smart Cities-Indicators, ICS 13.020.20. The indicators were divided into core indicators (the essential criteria required for city) and supporting indicators (representing the best practices implemented in the city) [16]. Indian School of Business developed Smart Cities Index (SCI) for evaluating cities [17]. The approach gives a framework for ranking of cities and calculation of Smart City Index. For easier understanding, a three level hierarchy was created with characteristic at the top level, factor at the middle level and indicators at the lowest level. Among six characteristics of smart cities considered at top level, environmental parameters were included in two characteristics: Living as well as Environment. Water supply (Access to water supply, and Adequacy of water supply), Solid waste (Access to solid waste collection), Drainage (Coverage of storm water drains, Quality of storm water drainage facilities), Sewerage (Access to sewerage network, Sanitation (Access to household sanitation and Access to public sanitation) were considered as factors (and indicators) under Living Characteristics of a smart city. Air Pollution (PM2.5 concentration), Noise Pollution (L-EQ-Levels) and Sustainability (Sewage recycling, Solid waste recycling and Use of renewable energy) were considered as factors (and respective indicators) under Environment characteristics.

Bosch et.al in 2017 [18] developed City Key Indicators for smart city projects and smart cities. This index compares the impact before and after the implementation of Smart City Project. Scores are provided to the indicators on the basis of the improvement made. These improvement scores are calculated for each indicator by different methods such as likert scale, normalisation etc. Ministry of Urban Development, Government of India developed Liveability standards [19] in 2017. A total of 79 indicators were taken, 57 core and 22 supporting, divided into 15 categories. Weights were accorded to category index depending upon the four pillars of development, viz. physical, institutional, social and economic. Liveability Standards include environmental indicators such as assured water supply, waste water management, solid waste management, noise pollution, pollution of surface water bodies etc. The comparison shows that most of the environmental indicators which define the Smart Cities and Liveable Cities intersect each other.

\section{RESULTS OF THE THEMATIC ANALYSIS}

An overview of literature indicated that various frameworks and set of indicators developed have different scope of operations. Table II summarizes the number of environmental indicators considered in various frameworks of Sustainable Cities and Smart Cities. It gives a clear picture that Sustainable Cities focuses on environmental indicators. The framework of Sustainable Cities has given the priority to environmental indicators more than 50\% (Table II), while the framework given for Smart Cities gives priority to ICT and modern technological solutions. The weak connection between Smart Cities and environmental sustainability urges to reconstruct the framework for Smart Cities.

Tanguay [12] gave a venn diagram (Fig. 3) which depicts the necessary integration of the three fundamental elements of sustainability: environmental, social and economic aspects. From the venn diagram it can be seen that the sustainability can only happen in the overlap, which is the core area of the three fundamental elements. However, Adams, in 2006 [20] emphasised on the expansion of environmental elements in order to match the size of the other two circles to move Smart Cities towards Sustainable development. The intersection of criteria of liveability, sustainability and Smart Cities motivate us to move towards development of Sustainable Smart Cities.

Table II. Environmental indicators in Sustainable and Smart Cities Framework

\begin{tabular}{|c|c|c|c|}
\hline \multicolumn{3}{|c|}{ SUSTAINABLE CITIES } & \multirow[b]{2}{*}{$\begin{array}{c}\% \\
\text { contribution of } \\
\text { Environmental } \\
\text { Indicators } \\
\end{array}$} \\
\hline Reference & $\begin{array}{c}\text { Total No } \\
\text { of } \\
\text { Indicators }\end{array}$ & $\begin{array}{c}\text { No of Environmental } \\
\text { Indicators }\end{array}$ & \\
\hline $\begin{array}{c}\text { Organisation } \\
\text { for Economic } \\
\text { Co-Operation } \\
\text { and } \\
\text { Development } \\
\text { [8] }\end{array}$ & $\begin{array}{c}50 \text { core } \\
\text { indicators. }\end{array}$ & $\begin{array}{c}\text { All the indicators } \\
\text { related to integration of } \\
\text { Transportation } \\
\text { agriculture } \\
\text { energy-environment).10 } \\
\text { key environmental } \\
\text { indicators related to air, } \\
\text { water and natural } \\
\text { resources. } \\
\end{array}$ & $100 \%$ \\
\hline $\begin{array}{c}\text { World Bank } \\
\text { Environment } \\
\text { Department } \\
\text { (WBED) [9] }\end{array}$ & 9 & 8 & $88 \%$ \\
\hline $\begin{array}{c}\text { Green City } \\
\text { Index (GCI) } \\
{[10]} \\
\end{array}$ & 30 & 19 & $63.33 \%$ \\
\hline $\begin{array}{c}\text { Urban } \\
\text { Sustainability } \\
\text { Index (USI) } \\
{[12]} \\
\end{array}$ & 16 & 10 & $62.5 \%$ \\
\hline \multicolumn{3}{|c|}{ SMART CITIES } & \\
\hline $\begin{array}{c}\text { Smart cities } \\
\text { model [11] }\end{array}$ & 33 & 4 & $12.12 \%$ \\
\hline $\begin{array}{c}\text { Environmental } \\
\text { Guideline For } \\
\text { Smart Cities } \\
\text { [13] }\end{array}$ & 26 & 7 & $26.92 \%$ \\
\hline $\begin{array}{l}\text { Assessment of } \\
\text { critical } \\
\text { success factors } \\
\text { for Smart } \\
\text { Cities [15] }\end{array}$ & 66 & 8 & $12.12 \%$ \\
\hline $\begin{array}{c}\text { Smart Cities } \\
\text { Indicators [16] }\end{array}$ & 93 & 28 & $30.10 \%$ \\
\hline $\begin{array}{c}\text { Smart Cities } \\
\text { Index: A tool } \\
\text { for } \\
\text { Evaluating } \\
\text { Cities [17] }\end{array}$ & 58 & 13 & $22.41 \%$ \\
\hline $\begin{array}{l}\text { CITY keys } \\
\text { indicators for } \\
\text { smart city } \\
\text { projects and } \\
\text { smart cities } \\
{[18]}\end{array}$ & 100 & 10 & $10 \%$ \\
\hline
\end{tabular}




\begin{tabular}{|c|c|c|c|}
\hline $\begin{array}{c}\text { Liveability } \\
\text { standards in } \\
\text { Cities [19] }\end{array}$ & 79 & 19 & $24.05 \%$ \\
\hline
\end{tabular}

(EF) as shown in equation 2. It will serve as a unidirectional scale to assess the quality of life and help the policy makers to draft the action plan for improvement towards Sustainable Smart Cities.

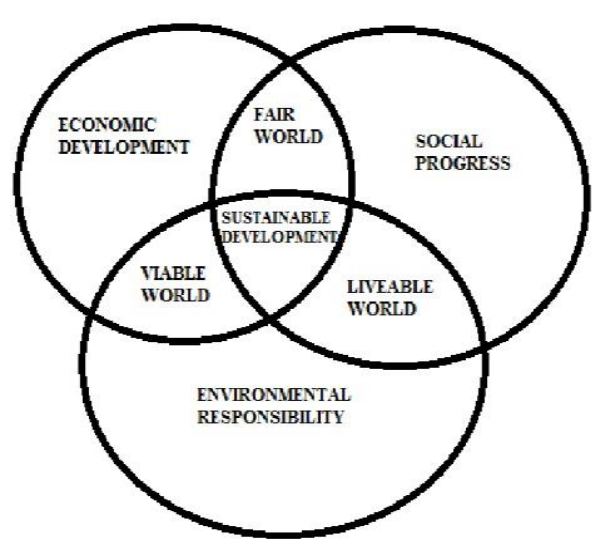

$$
\mathrm{EF}=\sum_{i=1}^{n} W i * X i
$$

(1)

Wi $=$ Weight of $i^{\text {th }}$ indicator; $\mathrm{Xi}=$ Data available for the individual indicators in the scale of 0 to $1 ; \mathrm{n}=$ number of indicators used for calculating EF; $\sum_{i=1}^{n} W i=1$

SSCEI $=\Sigma($ SWM + WSM + SAS + SWD + AEC $)$

Sustainable Smart Cities Environmental Index (SSCEI) developed will guide the investments and monitor the progressive environmental development of cities under Smart Cities Mission (SCM) in India.

\section{CONCLUSIONS}

Fig.3. Standard Dimensions of Sustainable Development [12]

\section{PROPOSED METHODOLOGY FOR SUSTAINABLE SMART CITIES ENVIRONMENTAL INDEX}

The overview of literature indicates that significant development has been taken place in the direction of Smart Cities and Sustainable Cities separately. The review shows that there is ambiguity vis to vis intermixing/overlap of indicators which envelop a complexity and confusion to decision makers. Moreover, no study has been conducted for Smart Cities in context to the Environmental Sustainability. As the framework developed till now did not use a holistic approach, a framework has been suggested, which will add an additional depth to the research of Sustainable Smart Cities. The foremost step towards developing a framework for Sustainable Smart Cities is to select appropriate indicators. The indicators selected must be reliable, able to measure sustainability and smartness quotient, convey clear picture and should abide the criteria given by Governmental agencies [21]. Based on the indicators given by Smart Cities Mission [3] it can be selected for five broad environmental dimensions: Solid Waste Management (SWM), Water Supply Management (WSM), Sewerage and Sanitation (SAS), Storm Water Drainage (SWD) and Ambient Environment Conditions (AEC). After, selecting indicators benchmarking should be done for each indicator which will reflect the performance level of the indicators. It will not only help in the monitoring and comparing the cities performance but also serve as a guiding element for investing the fund in the targeted indicator in which the city has performed poor. As the selected indicators do not carry equal importance, hence weights should be assigned according to relative importance. After assigning weights, the data collected for each indicator, must be multiplied as per equation 1 ,and then summed up to obtain the value of environmental factors (EF). The last step is to develop a Sustainable Smart Cities Environmental Index (SSCEI), by the help of selected indicators on a relative scale of 0 to 100 . SSCEI is calculated by summing up the values of all the environmental factors

This paper generated a new insight on the weak connection between Smart Cities and environmental sustainability through the findings of comprehensive literature review focussing on the available frameworks for Sustainable and Smart Cities. According to Ahvenniemi [22] 'a city that is not sustainable is not really smart'. Hence, priority should be given to develop "Sustainable Smart Cities". In this direction a framework has been suggested that in turn will help in strategic planning for investing the funds, and implement the action plan for development, keeping in view the coherent vision of developing Sustainable Smart Cities in India.

\section{ACKNOWLEDGEMENTS}

All the necessary facilities for this work have been provided by the Indian Institute of Technology (Banaras Hindu University) Varanasi.

\section{REFERENCES}

1. Randhawa A. \& Kumar A.Exploring sustainability of smart development initiatives in India.- International Journal of Sustainable Built Environment,6:701-710, 2017.

2. Cohen B. What exactly is a smart city?.2012-Retrieved from http://www.fastcoexist.com/1680538/what-exactly-is-asmart-city .(Accessed on 26 February 2014).

3. MoUD. Mission statements and Guidelines. 2015a. Retrievedfromhttp://smartcities.gov.in/upload/uploadfiles/files/SmartCi tyGuidelines(1).pdf

4. MoUD. Jawahar nehru national urban renewal mission.2006.

5. MoUD.(2015b): Atal Mission for Rejuvenation and Urban Transformation.- $\quad$ Retrieved from http://amrut.gov.in/writereaddata/AMRUT Guidelines .pdf

6. MoHUA. Heritage City Development and Augmentation Yojana. 2017. Retrieved from http://hridayindia.in/

7. Bibri Se.\& Krogstie J. Smart Sustainable Cities of the Future: An Extensive Interdisciplinary Literature Review.-Sustainable Cities and Society, 31:183-212. 2017.

8. OECD. Environmental Indicators Towards Sustainable Development. 2001. Retrieved from

https://www.oecd.org/site/worldforum/33703867.pdf

9. Segnestam, L. Indicators of Environment and Sustainable Development, 89. 2002.

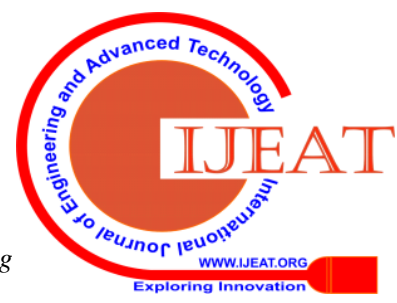


10. EIU. The Green City Index. The Economist Intelligence Unit (EIU). 2012. Retrieved from http://aiph.org/wp-content/uploads/2015/04/GreenCity Guidelines.pdf

11. Lazaroiu, C. \& Roscia, M.: Definition methodology for the smart cities model.- Energy, 47:326-332. 2012.

12. Indicators For Sustainable Cities. Science for Environment policy.12. 2015.

13. MEM. Cleaner Greener \& safer Mauritius, Environmental Guideline for Smart Cities.Ministry of environment, sustainable development, and disaster and beach management. 2015

14. Joshi S., Saxsena S.,Godbole T.,\& Shreya. Developing Smart Cities : An Integrated Framework.- Procedia Computer Science,93:902-909. 2016.

15. Sureshchandra M.S., Bhavsar J.J., \& Pitroda R.J. Assessment Of Critical Success Factors for Smart Cities Using Significance Index Method. -International Journal of Advance Research And Innovative Ideas In Education, 2(3):802-810. 2016.

16. BIS. “Smart Cities-Indicators"ICS 13.020.20. 2016

17. ISB.Smart Cities Index A tool for Evaluating Cities.2017

18. Bosch P., Jongeneel S., Rovers V., Neumann H.M., Airaksinen M., \& Huovila A.:CITYkeys Indicators for smart city projects and smart cities.2017.

19. MoUD.Liveability Standards in Cities, 35.2017. Retrievedfromhttps://smartnet.niua.org/sites/default/files/resources/Liv eability Standards.pdf

20. Adams W. M.The Future of Sustainability: Re-thinking Environment and Development in the Twenty-first Century.2006. Report of the IUCN Renowned Thinkers Meeting, 29-31 January 2006. IUCN.

21. Hak T., Janouskova S., \& Moldan B. Sustainable Development Goals: A need for relevant indicators.- Ecological Indicators,60:565-573.2016

22. Ahvenniemi H., Huovila A., Pinto-Seppa I., \& Airaksinen M.What are the differences between sustainable and smart cities?.-Cities, 60:234-245.2017

\section{AUTHORS PROFILE}

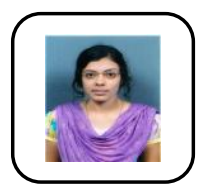

Shruti, Research Scholar, Department Of Civi Engineering, IIT(BHU), Varanasi, India.

Area of interest: Environmental Decision Support System, Smart Cities.

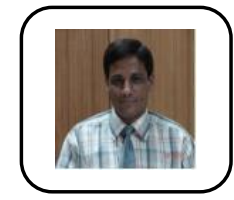

Prabhat Kumar Singh, Professor, Department Of Civil Engineering, IIT(BHU), Varanasi, India.

Area of interest: Environmental Engineering - Water Quality Control, Environmental Impact Assessment, River Health, Environmental Decision Support System.

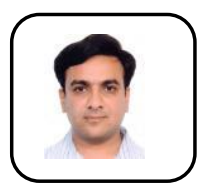

Anurag Ohri, Associate Professor, Department Of Civil Engineering, IIT(BHU), Varanasi, India.

Area of Interest: Remote Sensing, GIS, Surveying, Solid Waste Management, Aerial Photogrammetry, Image Processing. 